\title{
ANALISIS PENINGKATAN SUMBER DAYA APARATUR PENGELOLA SISTEM INFORMASI KESEHATAN PADA DINAS KESEHATAN KOTA PALOPO
}

\author{
FARMAWATI, ABD. HAPID
}

\begin{abstract}
ABSTRAK
Daerah dan Waktu penelitian

Perusahaan yang menjadi objek penelitian penulisan adalah Dinas

Kesehatan Kota Palopo. Adapun waktu penelitian yang digunakan dalam penulisan ini adalah selama dua bulan.

Data primer adalah data yang bersumber dari Kantor Dines Kesehatan Kota Palopo yang dilakukan dengan pengamatan secara langsung dengan pimpinan atau pegawai.

Data sekunder adalah data yang diperoleh dari dokumen-dokumen atau merupakan laporan tertulis Kantor DinesKota Palopo yang berkaitan dengan penulisan skripsi ini.

Populasi penelitian adalah staf/ pengawai pada Dinas Kesehatan Kota Palopo dan sampel yang penulisan tampilan adalah staf/ pengawai yang bertugas sebagai pengelola sistem informasi kesehatan pada Dinas kesehatan Kota Palopo.

Penempatan berdasarkan pendidikan

Penempatan tenaga tehnis pada dinas kesehatan kota palopo umumnya didasar pada latar belakang pendidikan formal yang pernah dienyam dan sebagian besar aparatur pada dinas kesehatan berlatarbelakang pendidikan kesehatan dan ditempatkan pada bagian-bagian yang erat kaitannya dengan pendidikan / keilmuan masing-masing. Sedangkan penempatan tenaga non teknis disesuaikan dengan kebutuhan masing-masing bagian maupun sub bagian. Penempatan aparatur berdasarkan pendidikan pada bagian dan sub bagian dinas kesehatan kota palopo.
\end{abstract}

Kata kunci: peningkatan, sumber daya, aparatur pengelola, sistem informasi kesehatan 


\section{Pendahuluan}

\section{Latar Belakang}

Dalam era globalisasi saat ini, begitu banyak sektor kehidupan yang tidak terlepas dari peran serta dan penggunaan teknologi komputer, terkhusus pada bidangbidangdan lingkungan pekerjaan. Semakin hari, kemajuan teknologi komputer, baik dibidang piranti lunak maupun perangkat keras berkembang dengan sangat pesat, disisi lain juga berkembang kearah yang sangat mudah dari segi pengaplikasi an dan murah dalam biyah. Solusi untuk bidang kerja apapun akan ada cara untuk dapat dilakukan melalui media komputer, dengan catatan bahwa pengguna juga harus terus belajar untuk mengiringi kemajuan teknologinya, sehingga pada akhirnya, solusi apapun teknologi yang kita pakai, sangatlah ditentukan oleh sumber daya manusia yang menggunakannya.

Dines kesehatan, sebagai salah satu instansi pelayanan kesehatan masyarakat akan melayani transaksi pasien dalam kesehariannya. Memberikan layanan dan tindakan dalam banyak hal akan mempengaruhi kondisi dan rasa nyaman bagi pasien. Semakin cepat akan semakin baik karena menyangkut nyawa pasien. Semakin kompleksnya jenis tindakan dan layanan yang harus diberikan, kesemuanya harus tetap dalam satu koordinasi terpadu karena selain memberikan layanan kesehatan, dinas kesehatan juga harus mengelola dana untuk membiayai operasionalnya. Masalah penelitian ini adalah bagai mana peningkatkan sumber Daya Aparatur pengelola Sistem Informasi kesehatan pada Kantor Dinas Kesehatan Kota Palopo?. Tujuan penelitian ini adalah untuk mengetahui dan menganalisis halhal yang dapat berpengaruh terhadap peningkatan sumber daya aparatur pengelola sistem informasi kesehatan dinas kesehatan kota palopo.

\section{Metodologi Penelitian}

Daerah dan Waktu penelitian

Perusahaan yang menjadi objek penelitian penulisan adalah Dinas Kesehatan Kota Palopo. Adapun waktu penelitian yang digunakan dalam penulisan ini adalah selama dua bulan.

\section{Metode Pengumbulan Data}

Metode pengumbulan data yang digunakan dalam penulisan ini yaitu (a) Penelitian lapangan (field Research); untuk pengumbulan data yang diperlukan, maka penulis mengadakan penelitian lapangan dengan jalan mengadakan peninjauan langsung pada objek penelitian dimana objek tersebut adalah kantor Dinas Kesehatan KotaPalopo, (b) Penelitian Kepustakaan (library Research); Penelitian yang dilakukan dengan cara mencari referensi yang merupakan buku-buku dan akses 
internet yang erat hubungannya dengan masalah yang dibahas sehingga dapat mempermudah dalam penyusunan.

Jenis Dan Sumber Data

(a) Data primer adalah data yang bersumber dari Kantor Dines Kesehatan Kota Palopo yang dilakukan dengan pengamatan secara langsung dengan pimpinan atau pegawai.

(b) Data sekunder adalah data yang diperoleh dari dokumen-dokumen atau merupakan laporan tertulis Kantor DinesKota Palopo yang berkaitan dengan penulisan skripsi ini.

Populasi dan sampel

Populasi penelitian adalah staf/ pengawai pada Dinas Kesehatan Kota Palopo dan sampel yang penulisan tampilan adalah staf/ pengawai yang bertugas sebagai pengelola sistem informasi kesehatan pada Dinas kesehatan Kota Palopo.

Metode Anilisis Data

Dalam menganalisis pembahasan penelitian bertujuan guna menyelesaikan pokok permasalahan dan untuk membuktikan hipotesis yang diambil tentang pendidikan dan pelatihan akan dapat mempengaruhi peningkatan sumber daya aparatur pengelolan sistem informasi kesehatan pada Dinas Kesehatan Kota Palopo, maka penulis menggunakan metode analisis penelitian deskriptif.

\section{Hasil Penelitian Dan Pembahasan}

Gambar Umum Dinas Kesehatan Kota Palopo

Penyelenggaraan pembangunan kesehatan selama ini disadari telah mampu meningkatkan derajatan kesehatan masyarakat secara bermakna, meskipun belum seluruhnya memuaskan. Oleh karena itu untuk mencapai masyarakat dengan derajat kesehatan tinggi perlu diselenggarakan pembagunan yang berkelanjutan melalui pelaksanan program secara menyeluruh, terarah dan terpadu dengan berdasar pada standar pelayanan manimal dan indikator indonesia sehat 2010. Selain itu, undangundang No 32 Tahun 2004 tentang pemerintahan daerah telah menetapkan bidang kesehatan sebagai salah satu kewenangan wajib yang harus dilaksanakan oleh pemerintahan daerah.

Kedudukan, tugas pokok dan fungsi

Kedudukan

Berdasarkan peraturan daerah kota palopo Nomor : 3 Tahun 2007 pembentukan susunan organisasi dan tatakerja lembaga tehnis daerah kota palopo, maka dinas kesehatan kota palopo dipimpin oleh kepala dinas kesehatan kota palopo 
yang berada dan bertanggungjawab kepada wali kota palopo melalui sekretarias daerah kota.

Tugas pokok

Dinas kesehatan kota palopo mempunyai tugas melaksanakan kewenangan desentralisasi di bgidang kesehatan dan tugas lain yang diberikan oleh wali kota. Fungsi

a. Perumusan kebijakan teknis dalam bidang kesehatan

b. Pemberian perizinan dalam pelaksanan pelayanan umum

c. Pembinaan terhadap unit pelaksana teknis dinas

d. Pelaksanan tugas lain sesuai dengan peraturan perundang-undangan yang berlaku

Analisis dan pembahasan

Kondisi sumber daya aparatur

Aparatur adalah merupakan unsur utama dalam penyusunan organisasi. Berjalannya roda organisasi bergantung pada aktifitas aparatur dan sumber daya didalamnya. Kondisi pegawai pada dinas kesehatan kota palopo dari data tahun 2010 berjumlah 62 orang termasuk data pegawai negeri sipil sebanyak 50 orang dan pegawai non PNS sebanyak 12 orang.

Dari jumlah yang ada, tidak semua pegawai dengan latar belakang pendidikan kesehatan. Komposisi aparatur dinas kesehatan kota palopo berdasarkan pendidikannya sebagai berikut:

Tabel 5.1

Komposisi PNS dinas kesehatan kota palopo

\begin{tabular}{|c|c|c|c|c|c|c|}
\hline \multirow[b]{2}{*}{ No. } & \multirow{2}{*}{$\begin{array}{l}\text { JENJANG } \\
\text { PENDIDIKAN }\end{array}$} & \multicolumn{3}{|c|}{ JENIS PENDIDIKAN } & \multirow{2}{*}{$\begin{array}{l}\text { NON } \\
\text { PNS }\end{array}$} & \multirow{2}{*}{\begin{tabular}{|l} 
JUMLAH \\
(ORANG)
\end{tabular}} \\
\hline & & \multirow{2}{*}{$\begin{array}{l}\text { KESEHATAN } \\
4 \\
\end{array}$} & \multicolumn{2}{|c|}{\begin{tabular}{|l} 
NON \\
KESEHATAN
\end{tabular}} & & \\
\hline 1 & Strata Dua (S.2) & & 0 & 0 & 0 & 4 \\
\hline 2 & Strata Satu (S.1) & 27 & 2 & 1 & 1 & 30 \\
\hline 3 & Diploma III & 3 & 3 & 1 & 1 & 7 \\
\hline 4 & Diploma I & 1 & 0 & 0 & 0 & 1 \\
\hline 5 & SMA/SMK/MAN & 2 & 7 & 10 & 10 & 19 \\
\hline 6 & SMP & 0 & 0 & 0 & 0 & 0 \\
\hline 7 & SD & 0 & 1 & 0 & 0 & 1 \\
\hline \multicolumn{2}{|c|}{ JUMLAH } & 37 & 13 & 12 & 12 & 62 \\
\hline
\end{tabular}

Sumber Data : Sub bagian umum dan kepagawaian Dinas Kesehatan Kota Palopo

Penempatan aparatur

Penempatan berdasarkan pendidikan

Penempatan tenaga tehnis pada dinas kesehatan kota palopo umumnya didasar pada latar belakang pendidikan formal yang pernah dienyam dan sebagian besar aparatur pada dinas kesehatan berlatarbelakang pendidikan kesehatan dan 
ditempatkan pada bagian-bagian yang erat kaitannya dengan pendidikan / keilmuan masing-masing. Sedangkan penempatan tenaga non teknis disesuaikan dengan kebutuhan masing-masing bagian maupun sub bagian. Penempatan aparatur berdasarkan pendidikan pada bagian dan sub bagian dinas kesehatan kota palopo.

Pengaruh pendidikan dan pelatihan bagi pengelola sistem informadi kesehatan.

Sistem informasi kesehatan merupakan suatu pengolaan informasi diseluruh tingkat pemerintah secara sistematis dalam rangka penyelenggaraan pelayanan kepada masyarakat.

Pendidikan menjadi hal penting dalam pengelolaan sistem informasi kesehatan umumnya pada hal-hal yang membutuhkan penjelasan secara ilmiah. walaupum dalam pelaksanaannya dinas kesehatan belum mampu memenuhi permintaan atas aparatur yang memiliki latar belakang pendidikan yang sesuai karena keterbatasan kuota pada perekturan pegawai negeri sipil. Langkah-langkah yang diambil oleh kepala dinas kesehatan kota palopo guna memenuhi target terlaksananya sistem informasi kesehatan di kota palopo yaitu dengan mengikutkan pengelola sistem informasi kesehatan pada beberapa pelatihan, diantaranya:

1. Pelatihan pengelola sistem informasi kesehatan sulawesi selatan di makassar.

2. Pelatihan penggunaan software sistem informasi kesehatan oleh dinas kesehatan provensi sulawesi selatan di makassar.

3. Pelatihan pengelola sistem informasi kesehatan bagi pengelola sistem informasi kesehatan di puskesmas sekota palopo oleh dinas kesehatan provensi sulawesi selatan di palopo.

4. Pelatihan pengelola perangkat Hardware jaringan sistem informasi kesehatan oleh dinas kesehatan provensi sulawesi selatan di palopo.

5. Pelatihan penggunaan Software sistem informasi Manajemen Daerah ( SIMDA ) di palopo.

Dari berbagai macam pelatihan yang telah diikuti dan di laksanakan, manfaat yang dirasakan pegawai secara personal pada umumnya sama, antara lain:

1. Meningkatkan kecakapan dan keterampilan sesuai dengan kebutuhan dan bidang kerjanya.

2. Pegawai dapat mengikuti perkembangan ilmu pengetahuan dan teknologi yang sangat di butuhkan dalam melaksanakan dan menyelesaikan pekerjanya.

3. Meningkatkan semangat kerja dan menjadi motivasi dalam menyelesaikan tugas yang diberikan oleh atasan. 


\section{Penutup}

Kesimpulan penelitian ini adalah : (a) Bahwa sumber daya manusia adalah aset yang harus dijaga guna pengembangan dan keberhasilan suatu program dan mencapaian terget kinerja, (b) Dengan melihat analisis peningkatan sumber daya aparatur dinas kesehatan kota palopo utamanya pengelola sistem informasi kesehatan terlihat bahwa peningkatan kualitas terjadi setelah mengikuti pelatihanpelatihan, (c) Keberhasilan dalam meningkatan sumber daya aparatur tidak hanya ditentukan oleh proses pendidikan melainkan harus didukung dengan pelatihan yang berkelanjutan mengingat perkembangan ilmu pengetahuan dan teknologi yang kian pesat, (d) Dengan adanya pelatihan yang dilaksanakan bagi pengelola sistem informasi kesehatan dapat meningkatankan sumber daya serta motivasi kerja aparatur pengelola sistem informasi kesehatan. Adapun saran penelitian ini adalah: (a). Dengan $m$ kelihat kebutuhan akan sumber daya aparatur pengelola sistem informasi kesehatan pada dinas kesehatan kota palopo, kiranya dalam pengadaan aparatur dapat selektif melihat kebutuhan akan tuntutan kerja yang ada, (b) Diharapkan kiranya sumber daya aparatur pengelola sistem informasi kesehatan dapat dikembangkan dengan memberikan fasilitas pendukung sehingga pencapai target sistem informasi kesehatan di kota palopo dapat dicapai.

\section{Daftar Pustaka}

2010, Pembuatan Database Sistem Informasi Kesehatan, di akses tanggal 12 Agustus, http://www.siknas-online.co.id

,2010, Sistem Informasi Kesehatan, diakses tanggal 12 agustus, http://www.depkes.go.id/artikel.

,2010, Upaya penyempurnaan Sistem Informasi Kesehatan,

Diakses tanggal 12 Agustus, http://www.depkes.go.id/artikel

,2010, Ilmu ekonomi manajemen manajer, diakses tanggal 14 Agustus

2010, http://www.google.com

Handoko, hani, T , 1998, manajemen personalia dan sumber daya manusia,

Edisi kedua. BPFE, Yogyakarta.

Manullang, M. 1992, Dasar-Dasar manajemen, edisis keenem belas, Balai Aksara

Martoyo, susilo, 1994, Manajemen Sumber Daya Manusia, edisis ketiga, BPFE, Yogyakarta. 
Malayu, Hasibuan. S. P, 1997, MSDM (Dasar dan kunci keberhasilan) Edisis kesembilan, Gunung Agung

Slamet saksomo, 1997, Manajemen personalia, Erlangga, jakarta

Mathis. L. Robert, John N. Jackson, 2002, Manajemen Sumber Daya Manusia, edisi pertama, salemba 4

Prabu Mangkunegar. A. A. Anwera, 2000, MSDM Perusahaan, Edisi pertama. Remaja Rosdakarya Bandung

Keapmenkes Nomor 004/Menkes/SK/1/2003, Tentang Kebijakan dan Strategi Desentralisasi Bidang Kesehatan, jakarta

Kepmenkes Nomor 932/Menkes/SK/VIII/2002, Tentang Petunjuk Pelaksanaan Pengembangan Sistem Laporan Informasi Kesehatan Kabupaten / kota, jakarta

Peraturan Daerah Nomor 3 Tahun 2007 Tentabg Pembentukan Susunan Organisasi dan Tata Kerja Lembaga Tehnis Daerah Kota Palopo, palopo

Peraturan Daerah Nomor 3 Tahun 2008 Tentang Struktur Organisasi Dinas Kesehatan Kota Palopo, palopo

Undang- Undang Nomor 28 Tahun 1999 Tentang Penyelenggaraan Negara Yang Bersih dan Bebas korupsi, kolusi dan Nepotisme, Jakarta

Undang-Undang Nomor 32 tahun 2004 Tentang pemerintahan daerah telah menetapkan bidang kesehatan sebagai salah satu kewenangan wajib yang harus dilaksanakan oleh pemerintahan daerah, Jakarta 